\title{
SISTEM PENUNJANG KEPUTUSAN PENILAIAN KESEHATAN ORGANISASI KOPERASI MENGGUNAKAN METODE SIMPLE ADDITIVE WEIGHTING (SAW)
}

\author{
Nadya Oktavina \\ Program Studi Informatika \\ STMIK Kharisma Karawang \\ oktavina.nadya30@gmail.com
}

\author{
Dedih \\ Program Studi Informatika \\ STMIK Kharisma Karawang \\ dedihthea@gmail.com
}

\author{
Yessy Yanitasari \\ Program Studi Informatika \\ STMIK Kharisma Karawang \\ yessy.yanitasari@gmail.com
}

\begin{abstract}
ABSTRAK
Penilaian kesehatan merupakan proses untuk mengukur tingkat kesehatan koperasi simpan pinjam (KSP) dan usaha simpan pinjam (USP). Penilaian dilakukan terhadap organisasi koperasi pada perusahaan atau instansi. Ada 7 aspek penilaian kesehatan yaitu permodalan, kualitas aktiva produktif, manajemen, efisiensi, likuiditas, kemandirian, dan jatidiri. Dalam proses penilaian tidak jarang terjadi kesalahan dalam perhitungannya. Oleh karena itu dibuatlah sistem penunjang keputusan menggunakan metode Simple Additive Weighting dengan metode pengembangan System Development Life Cycle (SDLC) Waterfall, dengan 5 data koperasi diperoleh hasil nilai tertinggi 0,89 kategori sehat oleh kopkar Rs Bayukarta dan nilai terendah 0,71 kategori cukup sehat oleh KSP Tirta Karawang Sejahtera.
\end{abstract}

Kata Kunci : Penilaian Kesehatan, Organisasi koperasi, Sistem Penunjang Keputusan, Simple Additive Weighting, SDLC Waterfall

\section{PENDAHULUAN}

Koperasi adalah badan usaha yang beranggotakan orang seorang atau badan hukum koperasi melandaskan kegiatannya berdasarkan prinsip koperasi sekaligus sebagai gerakan ekonomi rakyat yang berdasar asas kekeluargaan sebagaimana dimaksud dalam Undang-undang Nomor 25 Tahun 1992 tentang Perkoperasian [3]. Dalam koperasi daerah terdapat beberapa anggota yang tergabung dari organisasi-organisasi sebuah perusahaan. Organisasi merupakan suatu hubungan kerjasama yang memiliki kepentingan dan tujuan yang sama yang terhubung melalui suatu wadah atau perkumpulan. Jadi organisasi koperasi merupakan wadah untuk mencapai tujuan yang mempunyai kepentingan yang sama atau kumpulan -tujuan dari individu yang mengacu pada pemuasan tujuan individu anggotanya. Didalam koperasi terdapat salah satu kegiatan yang tidak banyak diketahui oleh masyarakat, yaitu penilaian kesehatan. Penilaian kesehatan dilakukan untuk mengukur tingkat kesehatan KSP dan USP koperasi. Ruang lingkup penilaian kesehatan KSP dan USP koperasi terdapat beberapa aspek yaitu permodalan, kualitas aktiva produktif, manajemen, efisiensi, likuiditas, kemandirian dan pertumbuhan, jatidiri koperasi. Didalam proses penilaian kesehatan tidak jarang terjadi kesalahan dalam proses pemasukan data dan juga berpengaruh terhadap hasilnya, sehingga membutuhkan waktu yang lebih untuk mengolah satu data koperasi. Untuk mengantisipasi kesalahan tersebut, maka dibuatlah system penunjang keputusan (SPK) penilaian kesehatan. Metode yang digunakan yaitu metode simple additive weighting (SAW), metode ini dipilih karena metode ini menentukan nilai bobot untuk setiap attribute, dan dilanjutkan dengan proses peranGkingan sehingga hasil akhirnya akan terlihat sesuai dengan nilai terbesar dari proses perhitungan tersebut [6]. Sedangkan metode pembangunannya menggunakan system life development cycle (SDLC), SDLC terdiri dari beberapa fase yaitu project planning phase, analysys phase, design phase, implementation phase, dan support phase. Dengan rancangan system penunjang keputusan ini, diharapkan dapat membantu dalam proses penilaian kesehatan terhadap organisasi koperasi di dinas koperasi dan ukm kabupaten Karawang.

\section{METODE PENELITIAN}

2.1 Sistem Penunjang Keputusan (SPK)

Pada awal tahun 1970-an, Scott Morton pertama kali mengartikulasikan konsep penting DSS. Ia mendefiniskan DSS sebagai sistem berbsis komputer interaktif, yang membantu para pengambil keputusan untuk menggunakan data dan berbagai model untuk memecahkan masalah-masalah tidak terstruktur [7].

\subsection{Simple Additive Weighting (SAW)}


Metode Simple Additive Weight (SAW), sering juga dikenal dengan istilah metode penjumlahan terbobot. Konsep dasar Simple Additive Weight (SAW) adalah mencari penjumlahan terbobot dari rating kinerja pada setiap alternatif pada semua atribut [6].

$$
R i j=\left\{\frac{X i j}{\operatorname{Max} X i j}\right.
$$

Jika j adalah atribut keuntungan (Benefit)

$$
R i j=\left\{\frac{\operatorname{Min} X i j}{X i j}\right.
$$

Jika $j$ adalah atribut biaya (cost)

Dimana :

$\mathrm{r}_{\mathrm{ij}} \quad=$ Rating kinerja ternormalisasi

Max $_{\mathrm{ij}}=$ =Nilai maksimum dari setiap baris dan kolom

$\operatorname{Min}_{\mathrm{ij}}=$ =Nilai minimun dari setiap baris dan kolom

Kolom $\mathrm{X}_{\mathrm{ij}}=$ Baris dan kolom dari matriks

Dengan $\mathrm{r}_{\mathrm{ij}}$ adalah rating kinerja ternormalisasi dari alternatif $\mathrm{Ai}$ pada atribut $\mathrm{Cj} ; \mathrm{i}=1,2, \ldots \mathrm{m}$ dan $\mathrm{j}=$ $1,2, \ldots . n$.

$$
\boldsymbol{V} \boldsymbol{i}=\sum_{j=i}^{n} W j \boldsymbol{k} \boldsymbol{i} j
$$

Nilai Vi yang lebih besar mengindikasikan bahwa alternatif Ai lebih terpilih

Dimana :

$\mathrm{Vi} \quad=$ Nilai akhir dari alternatif

$\mathrm{Wi} \quad=$ Bobot yang telah ditentukan

Rij $\quad=$ Normalisasi matriks

Menurut Fishburn dan MacCrimmon ada beberapa langkah dalam penyelesaian Metode Simple Additive Weight (SAW) adalah sebagai berikut [2] :

1. Menentukan kriteria-kriteria yang dijadikan acuan dalam pendukung keputusannya yaitu

$\mathrm{Ci}$.

2. Menentukan rating kecocokan setiap alternatif pada setiap kriteria.

3. Membuat matriks keputusan berdasarkan kriteria (Ci).

4. Kemudian melakukna normalisasi matriks berdasarkan persamaan yang disesuaikan dengan jenis atribut (atribut keuntungan maupun atribut biaya) sehingga diperoleh matriks ternormalisasi R.

5. Hasil akhir diperoleh dari proses perangkingan yaitu penjumlahan dari perkalian matriks ternormalisasi $\mathrm{R}$ dengan vector bobot sehingga diperoleh nilai terbesar yang dipilih sebagai alternatis terbaik (Ai) sebagai solusi.

\subsection{System Development Life Cycle (SDLC)}

SDLC Waterfall adalah suatu metodologi pengembangan perangkat lunak yang mengusulkan pendekatan kepada perangkat lunak sistematik dan sekuensial yang mulai pada Project planning phase, Analysis phase, Design phase, Implementation phase, dan Support Phase [5].

a. Project Planning Phase

Didalam fase ini terdapat beberapa tahapan, yaitu mendefinisikan masalah, menghasilkan jadwal proyek, konfirmasi kelayakan proyek, menentukan staff dan peluncuran proyek

b. Analysis Phase

Dalam tahapan ini terdapat beberapa tahapan yaitu penemuan persyaratan, mengumpulkan informasi, tentukan persyaratan sistem, prioritaskan persyaratan, menghasilkam dan konversi data, latih pengguna dan dokumentasi sistem.

\section{c. Design Phase}

Untuk merancang sistem solusi berdasarkan persyaratan yang ditetapkan dan keputusan yang dibuat selama analisis di butuhkan beberapa tahapan yaitu merancang dan mengintegrasikan jaringan, desain arsitektur aplikasi, desain antarmuka pengguna, desain antarmuka system, 
merancang dan mengintegrasikan database, prototype untuk detail desain, dan merancang dan mengintegrasikan control system.

\section{d. Implementation Phase}

Adapun beberapa tahapan yang terdapat dalam fase implementasi yaitu bangun komponen perangkat lunak, verifikasi dan uji.

\section{e. $\quad$ Support Phase}

Fase yang terakhir dalam membangun sistem yaitu bagian yang ada dalam fase ini yaitu mempertahankan sistem, tingkatkan sistem dan mendukung pengguna. Mengevaluasi alternatif dan melakukan tinjau rekomendasi dengan manajemen.

\section{HASIL DAN PEMBAHASAN}

Berikut ini adalah gambar SDLC waterfall :

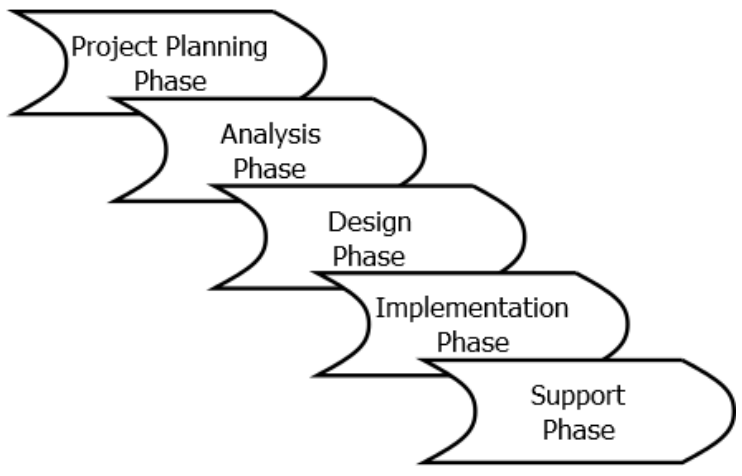

Gambar 1. SDLC Waterfall [5]

\subsection{Project Planning Phase}

a. Identifikasi Masalah

Menentukan masalah-masalah yang timbul dalam mengambil keputusan untuk penilaian kesehatan.

b. Pembuatan Jadwal

Pembuatan jadwal yang akan digunakan dalam penelitian yaitu dari februari sampai agustus.

c. Konfirmasi Kelayakan Proyek

Meliputi semua biaya yang dikeluarkan dan semua manfaat yang diperoleh.

d. Peluncuran Proyek

Proyek ini akan diluncurkan pada bulan agustus 2018.

\subsection{Analysys Phase}

1. Analisis Teori

Pada tahap ini dilakukan perhitungan terhadap hasil kriteria yang kemudian hasilnya sesuai dengan skor yang sudah ditentukan [7].

a. Realitas

Pada tahap ini realitas diuji, dan masalah diidentifikasi dan ditentukan

b. Fase Intelegensi

Pada tahap ini intelegensi dalam pengambilan keputusan meliputi pemindaian lingkungan, baik secara intermiten maupun terus menerus. Intelegensi mencakup berbagai aktivitas yang menekankan identifikasi situasi atau peluang-peluang masalah.

c. Fase Desain Pada tahapan desain meliputi penemuan atau mengembangkan dan menganalisis tindakan yang mungkin dilakukan,

d. Fase Pilihan

Pada tahapan pilihan adalah dibuatnya suatu keputusan yang nyata dan diambil suatu komitmen untuk mengikuti suatu tindakan tertentu.

e. Implementasi Solusi

Penerapan terhadapa rancangan sistem yang telah dibuat pada tahapan perancangan serta pelaksanaan alternatif tindakan yang telah dipilih pada setiap pemilihan.

Berikut gambaran pengambilan keputusan : 


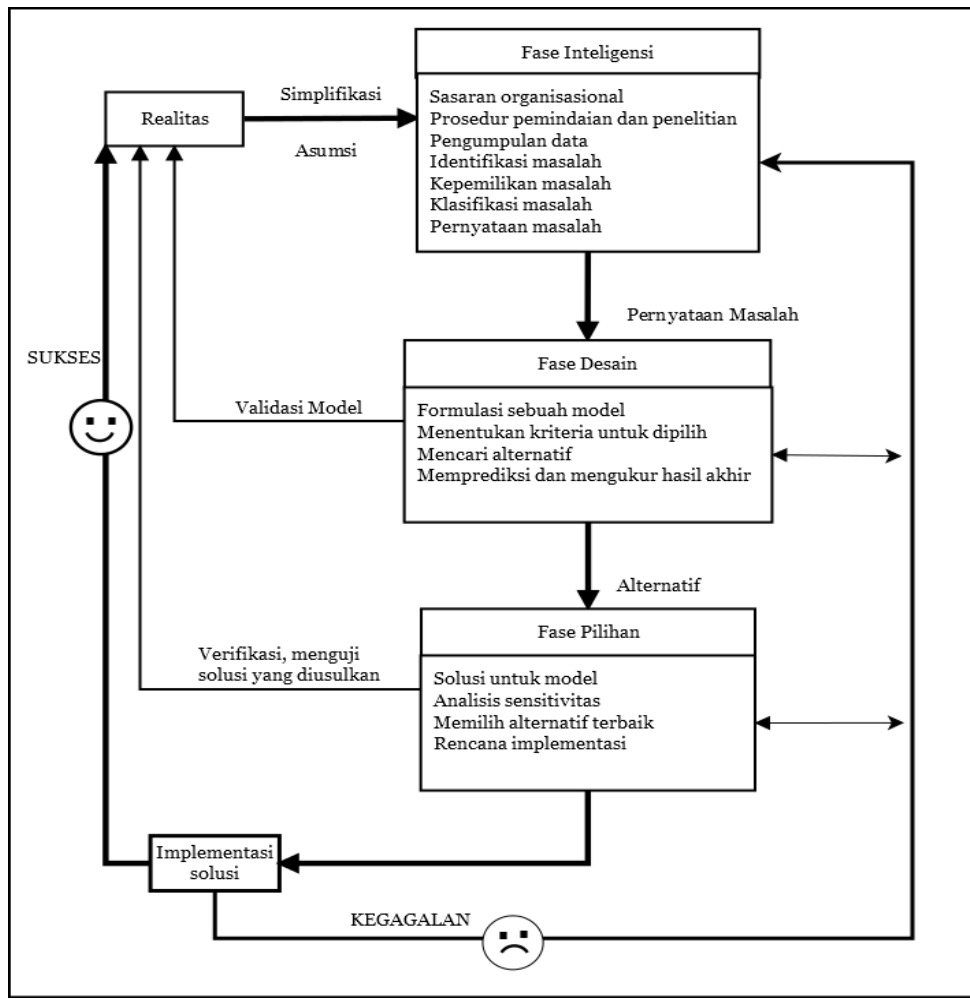

2. Analisis teori metode SAW :

Gambar 2. Pengambilan Keputusan [7]

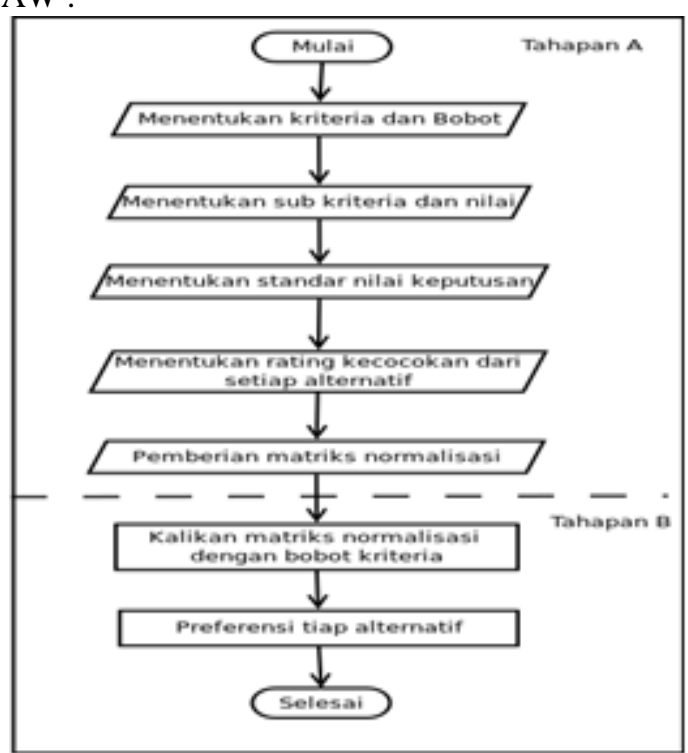

Gambar 3. Alur Metode SAW

\section{Penentuan Kriteria Metode Simple Additive Weight}

Sistem penilaian kesehatan menggunakan metode SAW. Untuk pengambilan keputusan terdapat beberapa kriteria dan nilai bobotnya. Pada pembahasan ini akan dijelaskan penerapan metode SAW dalam sistem ini.

Tabel 1 Ketentuan Kriteria

\begin{tabular}{lll}
\hline Kode Kriteria & Ketentuan Kriteria & \\
\hline $\mathrm{C} 1$ & Permodalan & \\
$\mathrm{C} 2$ & Kualitas & Aktiv \\
& Produktif & \\
\hline
\end{tabular}




\begin{tabular}{ll}
\hline Kode Kriteria & Ketentuan Kriteria \\
\hline C3 & Manajemen \\
C4 & Efisiensi \\
C5 & Likuiditas \\
C6 & Kemandirian \\
C7 & Jatidiri \\
\hline
\end{tabular}

Tabel 2 Alternatif Organisasi

\begin{tabular}{lll}
\hline Kode Alternatif & Organisasi & \\
\hline A1 & Kopkar Rs Bayukarta \\
A2 & Kopkar PT KIA & \\
A3 & KPRI Bima Karya & \\
A4 & KPRI Depag & \\
A5 & KSP Tirta Karawan \\
& Sejahtera & \\
\hline
\end{tabular}

Dari masing-masing kriteria tersebut akan ditentukan bobot penilaiannya, berikut tabel nya:

Tabel 3 Bobot Kriteria

\begin{tabular}{ll}
\hline Kode Kriteria & Bobot Nilai \\
\hline C1 & 15 \\
C2 & 25 \\
C3 & 15 \\
C4 & 10 \\
C5 & 15 \\
C6 & 10 \\
C7 & 10 \\
\hline Total & 100 \\
\hline
\end{tabular}

Setelah ditentukan kriteria dan pembobotan nilainya, selanjutnya ialah menentukan sub kriteria untuk masing-masing kriteria beserta penilaiannya berikut masing-masing tabel kriteria nya :

Tabel 4 Permodalan

\begin{tabular}{ll}
\hline Rasio & Nilai \\
\hline Rasio modal sendiri terhadap asset & 6 \\
Rasio modal sendiri terhadap pinjaman yang diberikan yang beresikı & 6 \\
Rasio kecukupan modal sendiri & 3 \\
\hline
\end{tabular}

Tabel 5 Kualitas Aktiva Produktif

\begin{tabular}{ll}
\hline Rasio & Nilai \\
\hline Rasio volume pinjaman pada anggota terhadap total volume pinjaman diberikal & 10 \\
Rasio risiko injaman bermasalah terhadap pinjaman diberikan & 5 \\
Rasio cadangan risiko terhadap risiko pinjaman bermasalah & 5 \\
Rasio pinjaman yang berisiko terhadap pinjaman yang diberikan & 5 \\
\hline
\end{tabular}

\begin{tabular}{ll}
\multicolumn{2}{c}{ Tabel 6 Manajemen } \\
\hline Rasio & Nilai \\
\hline Manajemen umum & 3 \\
Manajemen kelembagaa & 3 \\
Manajemen permodalan & 3 \\
Manajemen aktiva & 3 \\
Manajemen likuiditas & 3 \\
\hline
\end{tabular}

Tabel 7 Efisiensi

\begin{tabular}{ll}
\hline Rasio & Nilai \\
\hline Rasio beban operasi anggota terhadap brut & 4 \\
Rasio beban usaha terhadap SHU kotor & 4 \\
Rasio efisiensi pelayanan & 2 \\
\hline
\end{tabular}


Tabel 8 Likuiditas

\begin{tabular}{ll}
\hline Rasio & Nilai \\
\hline Pengukuran rasio kas bank terhadap kewajiban lancar & 10 \\
Pengukuran rasio pinjaman yang diberikan terhadap dana yang diterim & 5 \\
\hline
\end{tabular}

Tabel 9 Kemandirian

\begin{tabular}{ll}
\hline Rasio & Nilai \\
\hline Rasio rentabilitas asset & 3 \\
Rasio rentabilitas modal sendiri & 3 \\
& \\
Rasio kemandirian operasional pelayanan & 4
\end{tabular}

\begin{tabular}{ll}
\hline \multicolumn{2}{c}{ Tabel 10 Jatidiri } \\
\hline Rasio & Nilai \\
\hline Rasio partisipasi bruto & 7 \\
Rasio promosi ekonomi anggota & 3
\end{tabular}

Setelah diketahui bobot dari setiap kriteria maka dibuatlah tabel rating kecocokan dari setiap alternatif pada setiap kriteria. Nilai ini didapat dari hasil akhir setiap kriteria,yang ada pada data kertas kerja dinas koperasi dan ukm kabupaten karawang.

\begin{tabular}{llllllll}
\multicolumn{10}{c}{ Tabel 11 Rating kecocokan } \\
\hline & C1 & C2 & C3 & C4 & C5 & C6 & C7 \\
\hline A1 & 13,2 & 24 & 15 & 9 & 7,5 & 8,5 & 7 \\
A2 & 8,4 & 19 & 10,8 & 10 & 15 & 5,5 & 7 \\
A3 & 12 & 17,5 & 10,5 & 10 & 3,75 & 8,5 & 7 \\
A4 & 15 & 19 & 10,5 & 9 & 3,75 & 5,5 & 7 \\
A5 & 7,8 & 19 & 10,5 & 10 & 7,5 & 5,5 & 5,25 \\
\hline
\end{tabular}

Setelah dibuat tabel rating kecocokan, selanjutnya dilakukan normalisasi dengan cara menghitung nilai rating kinerja ternormalisasi $\left(\mathrm{r}_{\mathrm{ij}}\right)$ dari alternative $\mathrm{A}_{\mathrm{i}}$ pada kriteria $\mathrm{C}_{\mathrm{j}}$.

$$
\operatorname{Rij}=\left\{\frac{X i j}{M a x X i j}\right.
$$

Jika j adalah atribut keuntungan (Benefit)

$$
\mathrm{Rij}=\left\{\frac{M i n X i j}{X i j}\right.
$$

Jika j adalah atribut biaya (cost)

Dimana :

$\mathrm{r}_{\mathrm{ij}} \quad=$ Rating kinerja ternormalisasi

$\operatorname{Max}_{\mathrm{ij}}=$ Nilai maksimum dari setiap baris dan kolom

$\operatorname{Min}_{\mathrm{ij}}=$ Nilai minimun dari setiap baris dan kolom

Kolom $\mathrm{X}_{\mathrm{ij}}=$ Baris dan kolom dari matriks

Dikatakan kriteria keuntungan apabila nilai $\mathrm{x}_{\mathrm{ij}}$ memberikan keuntungan bagi pengambil keputusan, sebaliknya kriteria biaya apabila $\mathrm{x}_{\mathrm{ij}}$ menimbulkan biaya bagi pengambilan keputusan.

Berikut normalisasinya :
a. Permodalan
$\mathrm{R} 11=13.2 / 15=0.88$
$\mathrm{R} 21=8.4 / 15=0.56$
$\mathrm{R} 31=12 / 15=0.8$ 


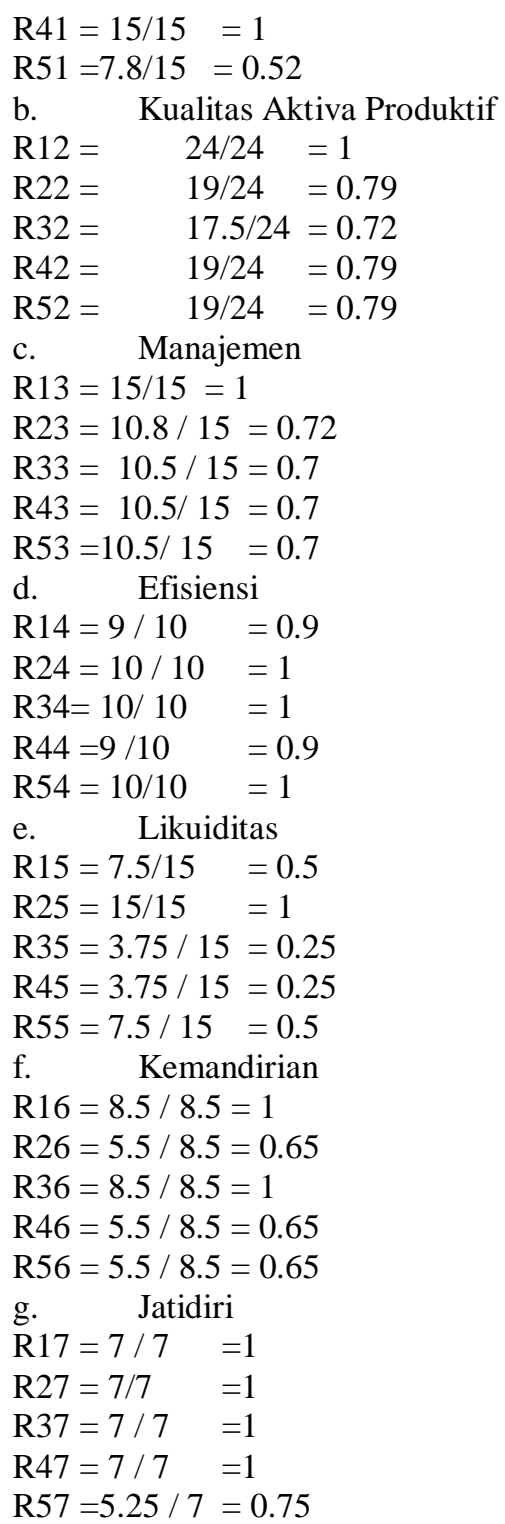

Hasil dari nilai rating kinerja ternormalisasi $\left(\mathrm{r}_{\mathrm{ij}}\right)$ membentuk matriks ternormalisasi $(\mathrm{R})$, berikut tabel nya:

Tabel 12 Rating kinerja ternormalisasi

$\begin{array}{lllllll}0.88 & 1 & 1 & 0.9 & 0.5 & 1 & 1 \\ 0.56 & 0.79 & 0.72 & 1 & 1 & 0.65 & 1 \\ 0.8 & 0.73 & 0.70 & 1 & 0.25 & 1 & 1 \\ 1 & 0.79 & 0.70 & 0.9 & 0.25 & 0.65 & 1 \\ 0.52 & 0.79 & 0.70 & 1 & 0.5 & 0.65 & 0.75\end{array}$

Proses selanjutnya yaitu melakukan perangkingan,

$V i=\sum_{j=i}^{n} W j R i j$

Nilai Vi yang lebih besar mengindikasikan bahwa alternatif Ai lebih terpilih.

Dimana :

$\begin{array}{ll}\mathrm{Vi} & =\text { Nilai akhir dari alternatif } \\ \mathrm{Wi} & =\text { Bobot yang telah ditentukan } \\ \mathrm{Rij} & =\text { Normalisasi matriks }\end{array}$ 
Jadi :

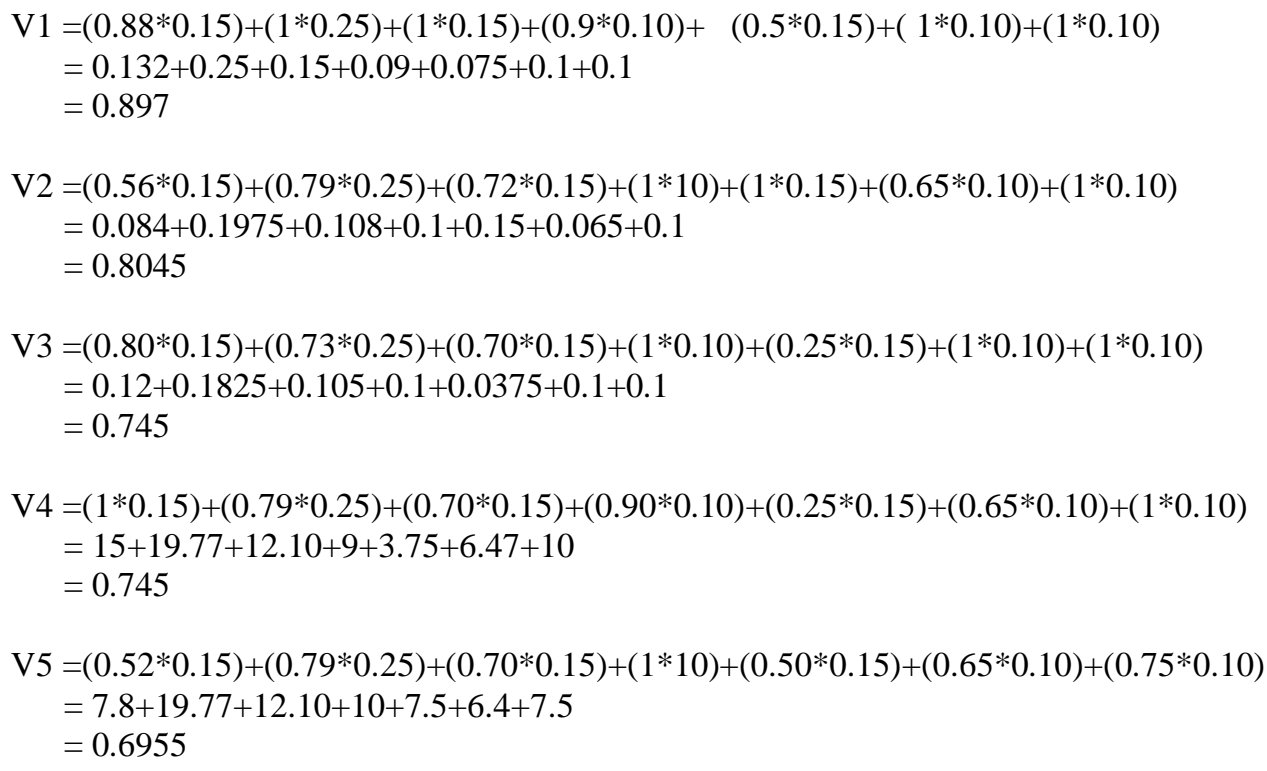

Berdasarkan hasil perhitungan diatas maka diperoleh hasil sebagai berikut:

Tabel 13 Penilaian

\begin{tabular}{llll}
\hline No & Nama Organisas Nilai & Kategori \\
& Koperasi & & \\
\hline 1 & Kopkar Rs Bayukarta & 0.897 & Sehat \\
2 & Kopkar PT KIA & 0.8045 & Sehat \\
3 & KPRI Bima Karya & 0.745 & Cukup Sehat \\
4 & KPRI Depag & 0.745 & Cukup Sehat \\
5 & Ksp Tirta Karawang. & 0.6955 & Cukup Sehat \\
& Sejahtera & & \\
\hline
\end{tabular}

Maka dapat disimpulkan V1, V2, V3, V4, dan V5 dengan nilai terbesar adalah V1 yaitu kopkar rs bayukarta dan nilai teendah V5 yaitu ksp tirta karawang sejahtera. Organisasi koperasi yang mendpatkan nilai <80, dinas koperasi akan melakukan pembinaan dari segi laporan keuangan dan membantu agar nilai organisasi koperasi tersebut dapat lebih baik lagi.

\subsection{Analysis System}

Diagram usecase berfungsi untuk mendefinisikan elemen fungsi-fungsi yang dibutuhkan pada perangkat lunak yang akan dibuat.

a. System Activities (UseCase Diagram) 
Techno Xplore

ISSN: 2503-054X

Jurnal Ilmu Komputer dan Teknologi Informasi

Vol. 4 No: 2, Oktober 2019

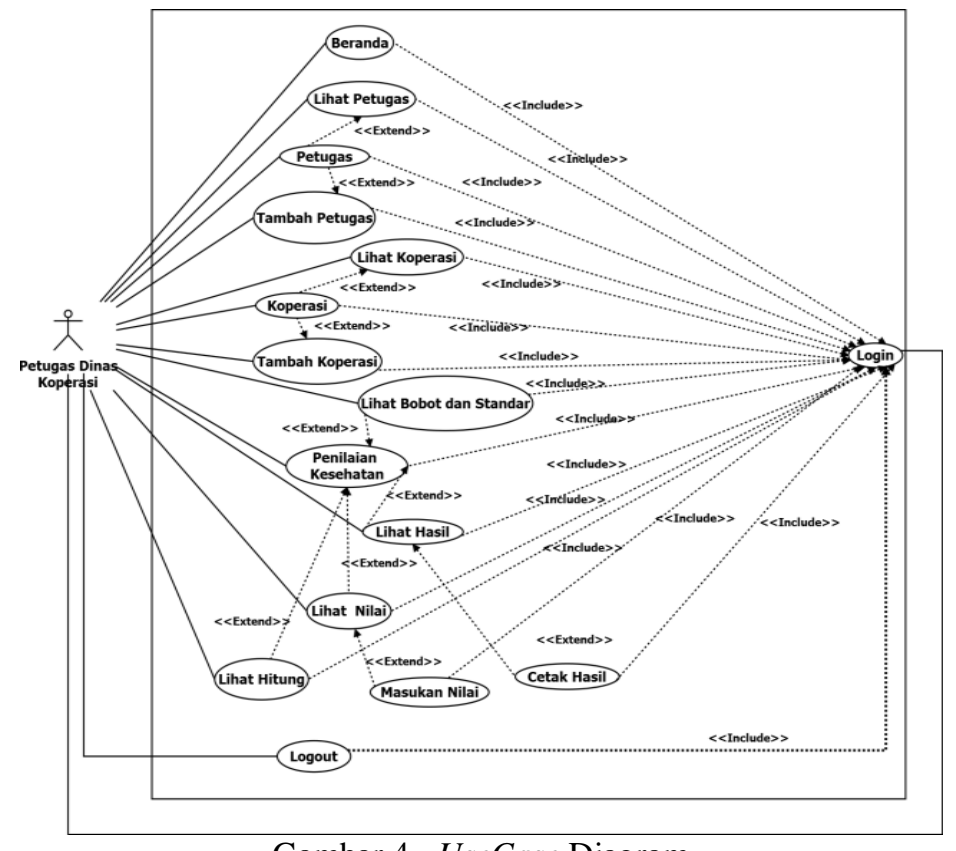

b. Class diagram (Class relation)

Gambar 4. UseCase Diagram

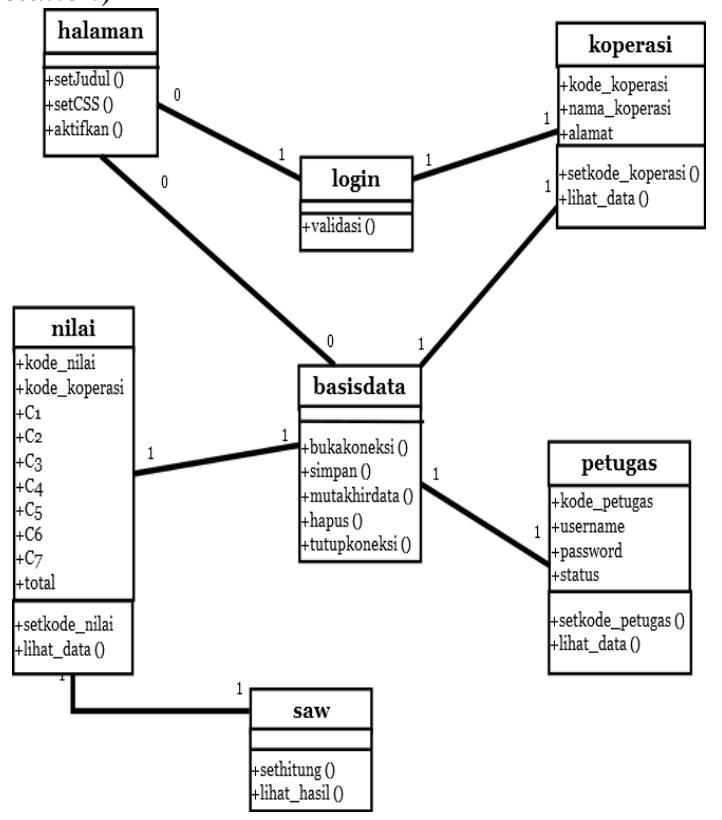

Gambar 5. Class relation

c. Object interaction (Sequence diagram)

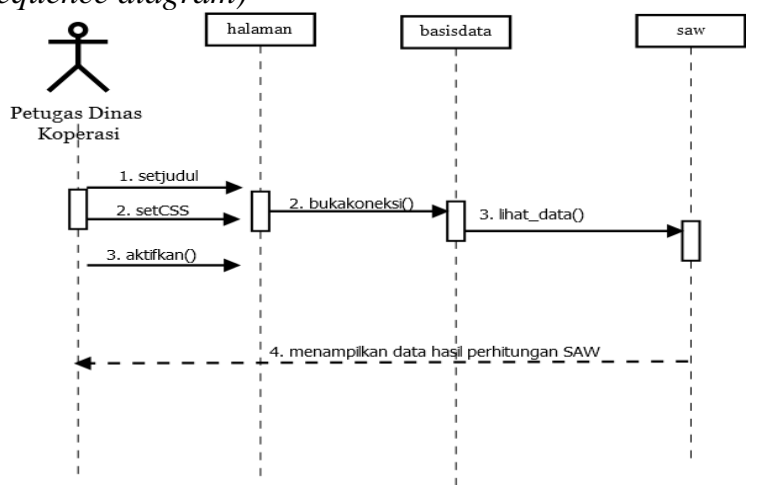

Gambar 6. Sequence diagram hasil hitung metode SAW d. Object behavior (activity diagram) 


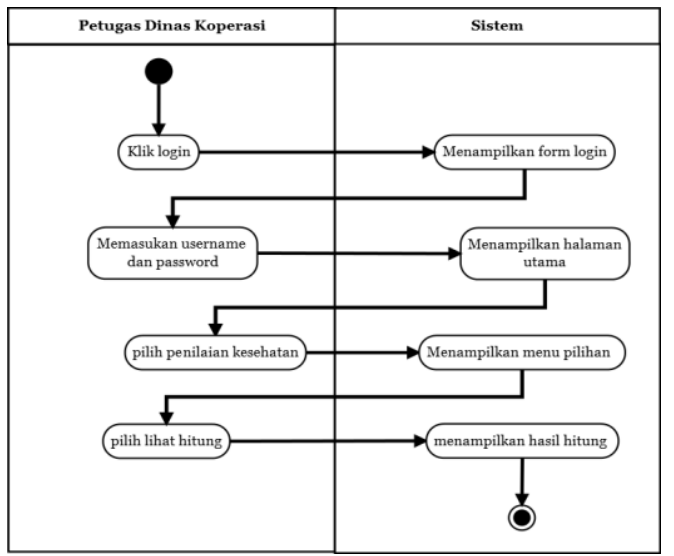

\subsection{Design Phase}

Gambar 7 Activity diagram lihat hitung metode SAW

Dalam tahap desai digunakan Object Oriented Design (OOD). Berikut adalah rancanan desain yang akan dibangun .

1. Desain Proses

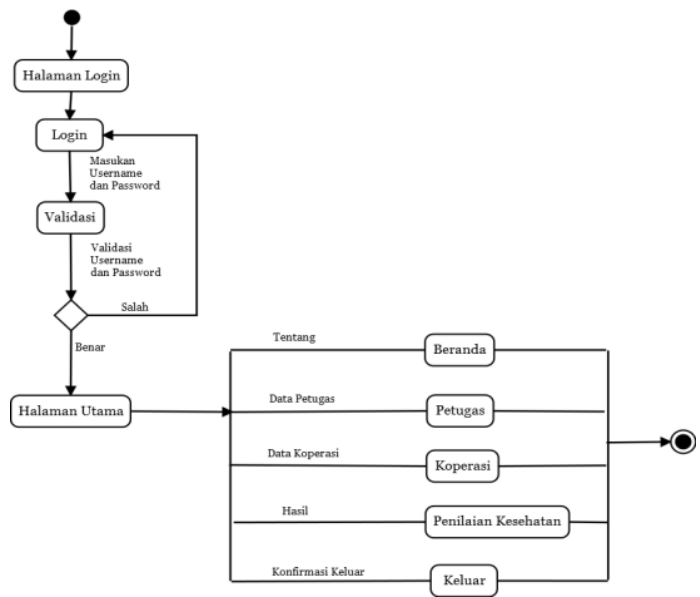

Gambar 8 Desain Proses

2. Desain Antarmuka

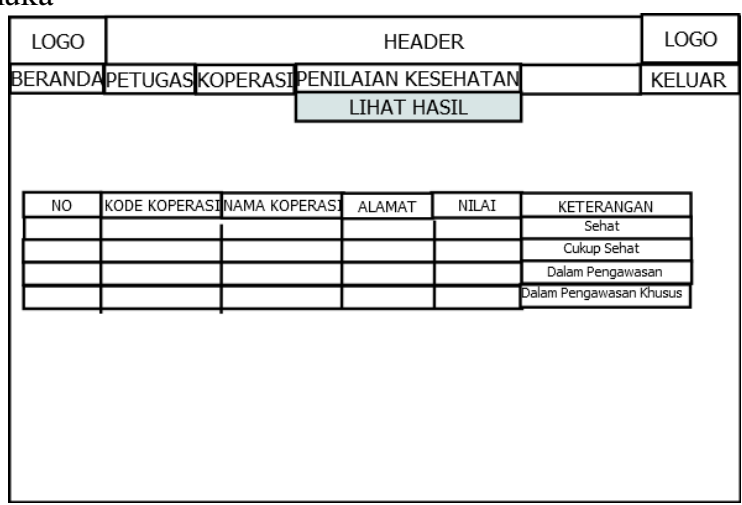

Gambar 9 Desain Halaman Lihat hasil

Berikut adalah gambar dari sistem yang telah dibuat : 


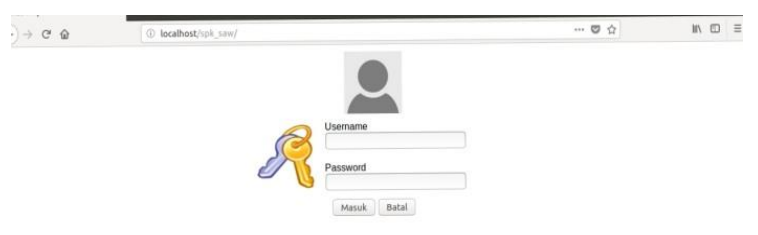

Gambar 10 Halaman Login

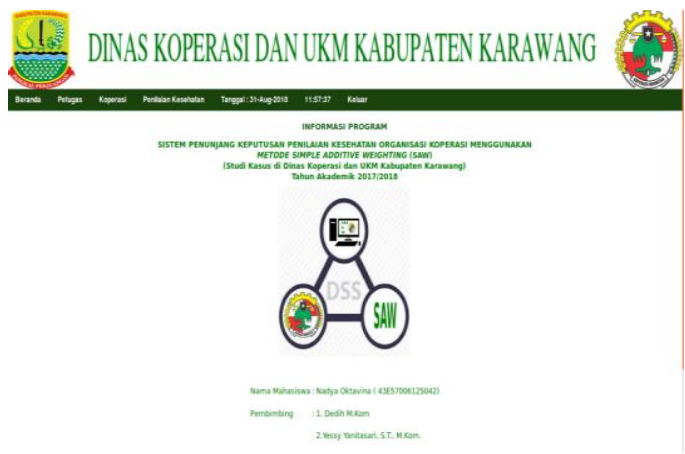

Gambar 11 Beranda

4. Hasil Perhitungan

Gambar berikut ini adalah hasil dari perhitungan metode SAW :

\section{Hasil}

\subsection{Implementation Phase}

\begin{tabular}{|l|l|l|l|l|l|l|l|l|l|}
\hline No & Nama & $\mathrm{C} 1$ & $\mathrm{C} 2$ & $\mathrm{C} 3$ & $\mathrm{C} 4$ & $\mathrm{C} 5$ & $\mathrm{C} 6$ & $\mathrm{C} 7$ & Nilai \\
\hline 1 & $\begin{array}{l}\text { KOPKAR Rs } \\
\text { Bayukarta }\end{array}$ & 0.132 & 0.15 & 0.15 & 0.135 & 0.075 & 0.15 & 0.15 & 0.897 \\
\hline 2 & $\begin{array}{l}\text { KOPKAR PT } \\
\text { KIA }\end{array}$ & 0.084 & 0.1188 & 0.108 & 0.15 & 0.15 & 0.0971 & 0.15 & 0.8046 \\
\hline 3 & $\begin{array}{l}\text { KPRI BIMA } \\
\text { KARYA }\end{array}$ & 0.12 & 0.1094 & 0.105 & 0.15 & 0.0375 & 0.15 & 0.15 & 0.7448 \\
\hline 4 & $\begin{array}{l}\text { KPRI } \\
\text { DEPAG }\end{array}$ & 0.15 & 0.1188 & 0.105 & 0.135 & 0.0375 & 0.0971 & 0.15 & 0.7451 \\
\hline 5 & $\begin{array}{l}\text { KSP TIRTA } \\
\text { KARAWANG } \\
\text { SEJAHTERA }\end{array}$ & 0.078 & 0.1188 & 0.105 & 0.15 & 0.075 & 0.0971 & 0.1125 & 0.6956 \\
\hline
\end{tabular}

Gambar 12 Hasil Perhitungan Metode SAW

\section{a. Pengujian Whitebox}

Whitebox testing merupakan pengujian yang memperhitungkan mekanisme internal sistem atau komponen. Whitebox testing menguji jalur perhitungan internal untuk mengidentifikasi bug dengan menyelidiki kebenaran struktur kode [1].

A. Flowgraph

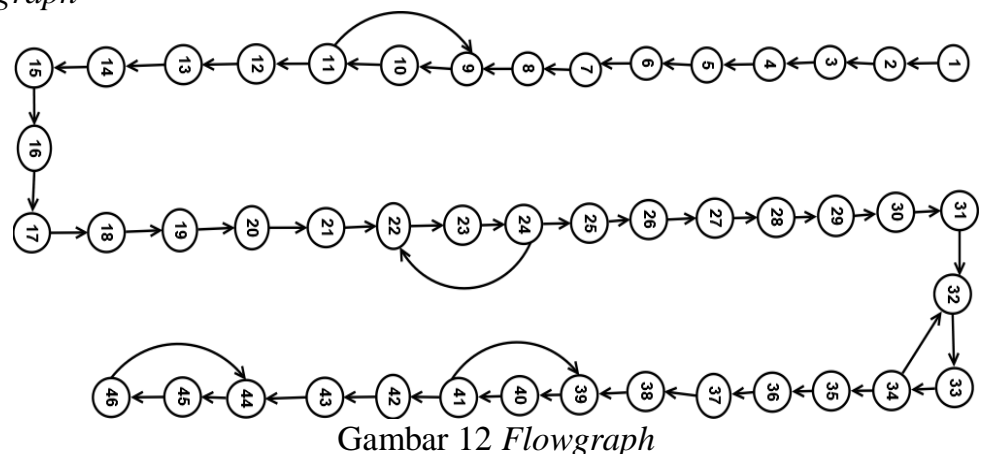

B. Cyclomatic Complexity

Perhitungan ini digunakan untuk menentukan jumlah independent Path yang akan ditelusuri.

a. $\mathrm{V}(\mathrm{G})=\mathrm{R}$ 


$$
\begin{aligned}
& =6 \\
& \text { b. } \begin{aligned}
& \\
& \\
& =6 \\
\text { c. } \mathrm{V}(\mathrm{G}) & =\mathrm{P}+1 \\
& = \\
& 5+1 \\
& =6
\end{aligned}
\end{aligned}
$$

Keterangan :

$$
\begin{array}{ll}
\mathrm{V}(\mathrm{G}) & =\text { Jumlah maksimal Independent Path } \\
\mathrm{R} & =\text { Jumlah region dari alur program } \\
\mathrm{E} \quad \text { = Jumlah edge atau garis penghubung dari alur program } \\
\mathrm{N} & =\text { Jumlah node atau simpul dari alur program } \\
\mathrm{P} & \text { = Jumlah decision atau pencabangan dari alur program }
\end{array}
$$

\subsection{Support Phase}

Aktifitas yang dilakukan dalam tahapan ini adalah maintenance system untuk memperbaiki kesalahan/ bug, dengan menambah fitur-fitur yang sekiranya diperlukan dimasa yang akan datang.

\section{KESIMPULAN DAN SARAN \\ 4.1 Kesimpulan}

Berdasarkan hasil analisis dan pembahasan, maka penulis menarik kesimpulan yaitu dengan memasukan nilai kriteria setiap koperasi ke dalam sistem, secara otomatis sistem akan menampilkan organisasi koperasi mana yang mendapat penilaian kesehatannya sehat, cukup sehat, dalam pengawasan, dan dalam pengawasan khusus. Organisasi koperasi yang mendapat nilai tertinggi dari 5 organisasi koperasi yaitu 0,89 adalah Kopkar Rs Bayukarta dan nilai terendah 0,71 diperoleh oleh KSP Tirta Sejahtera Karawang. Sehingga dengan dibangunnya sistem ini dapat mempermudah petugas untuk mengetahui hasil dari penilaian setiap organisasi koperasi.

\subsection{Saran}

Adapun saran yang dapat dilakukan adalah

1. Sistem penunjang keputusan ini bisa dikembangkan dengan data yang sudah ada dan sistem bisa dibuat menjadi lebih rinci lagi sesuai dengan data dari koperasi dengan menambahkan fitur-fitur lainnya yang mendukung proses penilaian kesehatan.

2. Sistem ini dapat dikembangkan dengan metode yang lain yaitu TOPSIS, AHP dan metode lainnya sesuai dengan kebutuhan.

\section{DAFTAR PUSTAKA}

[1] Galien Daniel, 2004. Software Quality Assurance. Pearson Education Limited, England

[2] Munthe, Hotmaria Ginting. 2013. Sistem Pendukung Keputusan Penentuan Prioritas Usulan Sertifikasi Guru Dengan Metode Simple Additive Weighting. Pelita Informatika Budi Darma Vol IV,No.2 Agustus 2013:52-58, ISSN : 2301-9425

[3] [MenKop] Peraturan deputi bidang pengawasan kementrian koperasi dan usaha kecil menengah republik indonesia. 2016. Tentang Pedoman Penilaian Kesehatan Koperasi Simpan Pinjam dan Unit simpan Pinjam Koperasi. No 06

[4] Resti Cintya Nalsa, 2017. Penerapan Metode Simple Additive Weighting (SAW) pada Sistem Pendukung Keputusan Pemilihan Lokasi untuk Cabang Baru Toko Pakan UD. Indo Multi Fish. Jurnal Intensif, Vol 1 No 2 Agustus 2017, pISSN: 2580-409X eISSN: 25496824 Kediri

[5] Satzinger, John W, Jackson, Robert B, dan Burd, Stephen D. 2010. Systems Analysis and Design in a Changing World, Fifth Edition. Course Technology, Boston.

[6] Sholikhah, Fatikhatus Satyareni Hernyka Diema Anugerah Sukma Chandra, 2016. Perancangan Sistem Pendukung Keputusan Pemilihan Pelanggan Terbaik Menggunakan Metode Simple Additive Weighting (SAW) Pada Bravo Supermarket Jombang. Jurnal Ilmiah Teknologi Sistem Informasi, Vol 2 No 1 eISSN :2502-3357 pISSN: 2503-0477 Jombang

[7] Turban E, Jaye Aronson, Peng-Liang Ting, 2005. Decision Support System and Intelegent System. Andi : Yogyakarta. 